\title{
TLR4 signals through islet macrophages to alter cytokine secretion during diabetes
}

\author{
Manesh Chittezhath ${ }^{1}$, Cho M M Wai ${ }^{1}$, Vanessa S Y Tay¹, Minni Chua ${ }^{1,2}$, Sarah R Langley ${ }^{1}$ and Yusuf Ali(D1,2,* \\ ${ }^{1}$ Lee Kong Chian School of Medicine, Nanyang Technological University Singapore, Singapore, Singapore \\ ${ }^{2}$ Singapore Eye Research Institute (SERI), Singapore General Hospital, Singapore, Singapore \\ Correspondence should be addressed to Y Ali: yusuf.ali@ntu.edu.sg \\ *(Y Ali is the lead author)
}

\begin{abstract}
Toll-like receptors (TLRs), particularly TLR4, may act as immune sensors for metabolic stress signals such as lipids and link tissue metabolic changes to innate immunity. TLR signalling is not only tissue-dependent but also cell-type dependent and recent studies suggest that TLRs are not restricted to innate immune cells alone. Pancreatic islets, a hub of metabolic hormones and cytokines, respond to TLR signalling. However, the source of TLR signalling within the islet remain poorly understood. Uncovering the specific cell source and its role in mediating TLR signalling, especially within type 2 diabetes (T2D) islet will yield new targets to tackle islet inflammation, hormone secretion dysregulation and ultimately diabetes. In the present study, we immuno-characterised TLRs linked to pancreatic islets in both healthy and obese diabetic mice. We found that while TLRs1-4 and TLR9 were expressed in mouse islets, these TLRs did not co-localise with insulinproducing $\beta$-cells. $\beta$-Cells from obese diabetic mice were also devoid of these TLRs. While TLR immunoreactivity in obese mice islets increased, this was driven mostly by increased islet endothelial cell and islet macrophage presence. Analysis of human islet single-cell RNA-seq databases revealed that macrophages were an important source of islet TLRs. However, only TLR4 and TLR8 showed variation and cell-type specificity in their expression patterns. Cell depletion experiments in isolated mouse islets showed that TLR4 signalled through macrophages to alter islet cytokine secretome. Together, these studies suggest that islet macrophages are a dominant source of TLR4-mediated signalling in both healthy and diabetic islets.
\end{abstract}

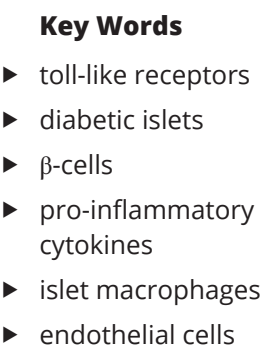

Journal of Endocrinology (2020) 247, 87-100

\section{Introduction}

Toll-like receptor (TLR) proteins provide immediate immune responses and link the innate immunity to the adaptive immunity arm when a more sustained immune response is required (Akira et al. 2001). Yet, TLRs have been shown to be expressed on a variety of nonimmune cell types such as endothelial, epithelial and endocrine cells in both mice and humans (Wen et al. 2004, Rifkin et al. 2005). Of the different TLRs, TLR2 and TLR4 have received much attention as metabolic sensors because their ligands, lipoteichoic acid (LTA) and lipopolysaccharides (LPS), respectively, resemble endogenous fatty acids. Both TLR2 and TLR4 respond to lipids (and its derivatives) and contribute to metabolic dysregulation states, such as insulin resistance (Shi et al. 2006, Konner \& Bruning 2011, Sun et al. 2012, Donath 2014). TLRs were also directly implicated in insulin-producing cell $\beta$-cell pathology. 
TLR2, TLR3 and TLR4, were strongly associated with $\beta$-cell dysfunction and apoptosis, particularly during autoimmune diabetes (T1D) (Rasschaert et al. 2005, Kim et al. 2007, Devaraj et al. 2008, Dogusan et al. 2008, Wen et al. 2008, Lee et al. 2011, Li et al. 2013, Burrows et al. 2015).

While many of these studies were well-designed with the use of pancreatic islets, they relied on secondary evidence that the various TLR transcripts were present in $\beta$-cells. For example, prior studies showed that mouse and human $\beta$-cells expressed transcripts for TLR2, TLR3, TLR4 and TLR9 (Vives-Pi et al. 2003, Wen et al. 2004). However, there remains a paucity of evidence on whether these various TLR proteins are indeed present on $\beta$-cells. TLR-signalling potentiates $\beta$-cell dysregulation. However, pancreatic islets contain other different cell types besides $\beta$-cells (e.g. other endocrine cells, vascular endothelial cells, sympathetic neurons, as well as macrophages). These other cell types may be the ones that are responsive to TLR ligands and may influence $\beta$-cell function through paracrine-mediated signalling.

Of the different cell-types, macrophages were shown to be an important source of TLR2 and TLR4 signalling. Within islets, partial macrophage depletion using clodronate-liposomes suppressed TLR-mediated cytokine secretion from cultured islets (Nackiewicz et al. 2014). However, a complete picture on islet macrophage contribution to TLR-mediated signalling remains hazy, especially in obese type-2 diabetic (T2D) islets. Hence, we first sought to determine TLR presence in both healthy and diabetic islets using validated and published antibodies with a focus on TLRs previously shown in islets. We show that $\beta$-cells are devoid of TLR2, TLR3, TLR4, TLR5 and TLR9 immunoreactivity in both healthy and diabetic islets. From the immunostaining results, we hypothesised that islet macrophages mainly contribute to TLR4-mediated cytokine secretion, especially in diabetic islets. To validate our results from mouse islets we also followed up with a TLR-expression analysis using human islet single-cell RNAseq datasets (Grun et al. 2016, Muraro et al. 2016, Segerstolpe et al. 2016, Lawlor et al. 2017).

\section{Materials and methods}

\section{Animals}

Twelve-week-old male homozygous diabetic (db/db) mice and non-diabetic lean littermates of the B6.BKS(D)-Leprdb/J (B6 db) mouse strain was purchased from the Jackson Laboratory and maintained on a $12 \mathrm{~h}$ light:12 $\mathrm{h}$ darkness cycle with free access to food and water. Mice were strictly age- and sex-matched within experiments and were handled in accordance with institutional and national guidelines. All animals were kept under non-SPF conditions and experiments were carried out with the approval of Institutional and University Ethics Committees (IACUC) of A*STAR (\#140905), and of NTU Singapore (\#A0373).

\section{Immunofluorescence determination}

Twelve-week-old lean and $\mathrm{db} / \mathrm{db}$ mice were killed and pancreas was excised. A portion of the tissue was fixed in $4 \%$ PFA at $4^{\circ} \mathrm{C}$ for $24 \mathrm{~h}$ and then placed in $30 \%$ sucrose solution for $24 \mathrm{~h}$ at $4^{\circ} \mathrm{C}$ and flash frozen with OCT. Pancreatic sections of $10 \mu \mathrm{m}$ were cut from frozen pancreas blocks using the CM1950 cryostat (Thermo Fisher Scientific) and stored at $-80^{\circ} \mathrm{C}$ until use. The frozen slides were thawed at room temperature for $1 \mathrm{~h}$ and washed with TBS-T three times for $5 \mathrm{~min}$ each. Sections were blocked with 10\% FBS in TBS-T or MOM Mouse Ig Blocking Reagent (for mouse-derived $\mathrm{MAB}$ staining) from the Vector MOM Immunodetection kit (Vector Laboratories) for $1 \mathrm{~h}$ at room temperature. Primary antibodies were diluted in 10\% FBS in TBS-T or MOM Diluent. The sections were pre-incubated in respective antibody diluent before primary antibody staining. The sections were stained with primary antibodies at $4^{\circ} \mathrm{C}$ overnight and at room temperature for $1 \mathrm{~h}$ the next day. The slides were washed three times in TBS-T before incubating in secondary antibodies for $1 \mathrm{~h}$ at room temperature. The sections were counterstained with DAPI nuclear staining during the secondary antibody incubation. Finally, the sections were mounted with Vectashield® (Vector Laboratories). Negative control assays were performed with primary isotype control (mouse IgG1 and rabbit IgG) antibodies. Antibodies used, their respective dilutions and references on their specificities (using KO tissues) are given (Tables 1 and 2). The pancreas samples were visualised on a ZEISS LSM800 Inverted confocal microscope. Imaging and quantification were performed using Zeiss LSM 800 (with airyscan) confocal laser scanning microscope (ZEISS) controlled with ZEN Blue image processing software. Immunofluorescence images of cell-type restriction were quantified using Image (NIH). Briefly, all nuclei (DAPIpositive) within an islet were first marked and counted (ImageJ) with the resulting value taken as a total number of islet cells. Next, we determined a number of immunopositive (either for insulin, glucagon, CD31, CD68 and/or 
Table 1 List of primary antibodies, clones and dilutions used for immunofluorescence.

\begin{tabular}{l} 
Primary antibodies (origin) \\
\hline CD31/PECAM-1 (goat) \\
CD68 (rat) \\
F4/80 (rat) \\
Glucagon (mouse) \\
IgG1 (mouse) \\
Insulin (guinea pig) \\
TLR-1 (rabbit) (Stridh et al. 2011) \\
TLR-2 (T2.5) (mouse) (Stridh et al. 2011) \\
TLR-3 (mouse) (Regel et al. 2019) \\
TLR-4 (mouse) (Uthaya Kumar et al. 2016) \\
TLR-5 (mouse) (Uchida et al. 2014) \\
TLR-9 (mouse) (Ilvesaro et al. 2008)
\end{tabular}

\begin{tabular}{l}
\hline Company \\
\hline R\&D Systems \\
Bio-Rad Laboratories \\
Bio-Rad Laboratories \\
Santa Cruz Biotechnology \\
Novus Biologicals \\
Dako (Agilent) \\
Novus Biologicals \\
Novus Biologicals \\
Novus Biologicals \\
Santa Cruz \\
Novus Biologicals \\
Novus Biologicals
\end{tabular}

\begin{tabular}{llc}
\hline Catalogue no. (Clone/Lot \#) & & Dilution \\
\cline { 1 - 1 } AF3628 (\#YZU0114021) & & $1: 200$ \\
MCA1957T (FA-11/ \#1708) & & $1: 800$ \\
MCA497RT (Cl:A3-1/ \#1605) & & $1: 200$ \\
SC-7779 (C018/ \#C0514) & & $1: 200$ \\
NBP1-97019 & & $1: 100$ \\
A056401 (\#10088287) & & $1: 100$ \\
NBP1-77244 (\#3639-0503) & $1: 100$ \\
NBP2-31222 (\#12023M0812A) & $1: 100$ \\
NBP2-24875 (40C1285.6/\#AB101606A-06) & $1: 100$ \\
SC-293072 (25/\#E0614) & $1: 100$ \\
NBP2-24787 (\#3694-0503) & $1: 100$ \\
NBP2-24729 (26C593.2/\#A-6) & \\
\hline
\end{tabular}

specific TLRs). These counts were then normalised to total islet cells and represented as percentage of cells that were immuno-positive (for a given marker) within an islet. A third round of counting registered cells that were double positive (e.g. CD31+/TLR4 ${ }^{+}$), which were again normalised against total islet cells (or total TLR4 ${ }^{+}$or total $\mathrm{CD} 31^{+}$or total $\mathrm{CD}^{2} 8^{+}$cells) and expressed as percentage of double positive cells within an islet. Six to 16 islets were imaged, quantified and averaged for each mouse (non-serial sections). Individual datapoints represent the averages of four independent mice in each group $(n=4)$.

\section{Pancreatic islet isolation, culture and ex vivo treatment}

Twelve-week-old lean and $\mathrm{db} / \mathrm{db}$ mice were killed and the pancreatic islets were isolated by collagenase P (Roche) injection into the common biliary duct followed by digestion and histopaque gradient separation as described previously (Carter et al. 2009). Islets were washed with RPMI-1640 medium and cultured in islet culture media,

Table 2 List of secondary antibodies and dilutions used for immunofluorescence.

\begin{tabular}{|c|c|c|c|}
\hline $\begin{array}{l}\text { Secondary antibodies } \\
\text { (origin) }\end{array}$ & Company & Catalogue no. & Dilution \\
\hline $\begin{array}{l}\text { Alexa } 488 \\
\text { anti-mouse (goat) }\end{array}$ & Thermo Fisher & A11029 & $1: 400$ \\
\hline $\begin{array}{l}\text { Alexa } 488 \text { anti-mouse } \\
\text { (donkey) }\end{array}$ & Thermo Fisher & A-21202 & $1: 400$ \\
\hline $\begin{array}{l}\text { Alexa } 488 \\
\text { anti-rabbit (donkey) }\end{array}$ & Thermo Fisher & A-21206 & $1: 400$ \\
\hline $\begin{array}{l}\text { Alexa } 568 \text { anti-rat } \\
\text { (rabbit) }\end{array}$ & Abcam & ab175719 & $1: 400$ \\
\hline $\begin{array}{l}\text { Alexa } 568 \text { anti-goat } \\
\text { (donkey) }\end{array}$ & Thermo Fisher & A-11057 & $1: 400$ \\
\hline $\begin{array}{l}\text { Alexa } 647 \text { anti-guinea } \\
\text { pig (donkey) }\end{array}$ & Jackson Immuno & $706-605-148$ & $1: 400$ \\
\hline
\end{tabular}

CMRL1066 (Life Technologies) for at least $4 \mathrm{~h}$ to allow for recovery. Isolated lean and $\mathrm{db} / \mathrm{db}$ islets $(\sim 100)$ were treated with or without AFS98 (100 ng/mL) for $\sim 36 \mathrm{~h}$. Islets were washed and cultured in the presence or absence of LPS (100 ng/mL) for $6 \mathrm{~h}$. Islets were collected under a stereomicroscope and snap frozen for whole-mount immunostaining. The supernatants were collected for cytokine analysis.

\section{Cytokine/chemokine analysis}

Approximately 100 mouse islets (lean and $\mathrm{db} / \mathrm{db}$ islets) were handpicked following isolation and cultured overnight in $6 \mathrm{~cm}$ non-coated sterile dishes containing $2 \mathrm{~mL}$ of CMRL-1066 medium. The islets were removed the next day and remaining culture media were collected for cytokine analysis. Media was first centrifuged at $1000 \boldsymbol{g}$ for $5 \mathrm{~min}$ and thereafter, $1 \mathrm{~mL}$ of supernatant was collected in a separate tube and concentrated to exactly half its volume $(500 \mu \mathrm{L})$ using a Speedvac (Concentrator Plus System, Eppendorf, Hamburg, Germany) at room temperature. Samples were then analysed for cytokines TNF $\alpha$, IL-1 $\beta$, IL-6, IL-10 and IL-18 by ELISA (Duoset ELISA development systems, R\&D Systems) (Chittezhath et al. 2019).

\section{Single-cell RNA sequencing analysis}

Processed datasets from four human pancreatic islet single-cell sequencing experiments (Grun et al. 2016, Muraro et al. 2016, Segerstolpe et al. 2016, Lawlor et al. 2017) were imported into $R$ from the Seurat website (https://satijalab.org/seurat/pancreas_integration_label _transfer.html). The datasets were analysed with Seurat 3 (Stuart et al. 2019), including normalisation, variable feature identification and anchored dataset integration 
using default parameters, unless otherwise specified. The variable features used for anchoring were identified using the default cut-off of the top 2000 variable genes, as determined by the standardised gene dispersion estimates across all cell types and across the four datasets, plus all TLRs; TLR4 and TLR8 were the only two TLRs identified in top 2000 variable genes. Cell clustering was performed using the uniform manifold approximation and projection (UMAP) implementation in Seurat 3 using the cell type labels provided in the processed dataset.

\section{Statistics}

Data collected were tested for normality (KolmogorovSmirnov) and thereafter expressed as mean \pm S.E.M. with a minimum of three independent experiments each. Number of mice used and number of independent experiments were reported in the figure legends. Sample size was determined before the start of the experiment using $\alpha=0.05$. Statistical significance was calculated by two-tailed Student's t-test or by ANOVA, as reported in each figure legend. $P \leq 0.05$ was considered as statistically significant.

\section{Results}

\section{TLRs are expressed in mouse pancreatic islets but do not co-localise with $\beta$-cells}

To test our hypothesis that islet cells other than $\beta$-cells express TLRs, we immunostained paraformaldehydefixed, mouse pancreatic sections (lean, non-diabetic heterozygotes of B6.BKS(D)-Leprdb/J line) with insulin and different TLRs, specifically TLR1, 2, 3, 4, 5 and 9, with validated commercially available antibodies (Ilvesaro et al. 2008, Stridh et al. 2011, Uchida et al. 2014, Uthaya Kumar et al. 2016, Regel et al. 2019). These TLR antibodies tested positive for cells of either the mouse spleen or liver (Supplementary Fig. 1, see section on supplementary materials given at the end of this article). Rabbit and mouse IgG isotype controls were added to mouse spleen sections (where TLR staining is robust) to rule out unspecific Fc receptor binding, a concern especially for mouse IgG1 monoclonal antibodies (Supplementary Fig. 1). In addition, previous studies showed that most of these TLR antibodies stained positively for murine tissues with specificities further validated using mouse knockout lines (TLR1, 2, 3, 4 and 9) (Table 1). Positive TLR1-4 immunostaining was detected in cells from mouse islets. TLR9 signal was weak while TLR5 was absent in mouse islets (Fig. 1). TLR1 staining did not co-localise with $\beta$-cells in the islet and its presence was strongest in a few cells located at the periphery of the islet, as well as in sporadic cells spread across the islet. TLR2 stained a subset of cells which did not co-localise with insulin-producing $\beta$-cells. TLR3 ${ }^{+}$cells were few, appeared elongated in shape and were randomly scattered within the islet. None of the TLR3+ cells stained positive for insulin, suggesting that TLR3 was not expressed in $\beta$-cells. TLR4 expression was strong at zones that corresponded to the peri-islet basement membrane. TLR4 ${ }^{+}$cells were also present and scattered within the islet. Again, none of the islet cells stained double positive for insulin and TLR4. TLR5 expression was extremely weak with no clear positivity in any islet cell, while TLR9 stained only a very small subset cells that were all insulin-negative (Fig. 1). These results suggest that none of the TLRs previously described within islets co-localised with $\beta$-cells.

\section{The expression of TLRs increased in diabetic mouse pancreatic islets but remained absent in $\beta$-cells}

We next proceeded to determine TLR immunoreactivity in obese diabetic islets. Diabetic islets were associated with increased TLR activation, inflammation and deterioration of $\beta$-cell function. We used the leptin receptor-deficient $(\mathrm{db} / \mathrm{db})$ mice as a model as these mice at 12-weeks of age displayed poor glycaemic control and considerable insulin resistance, despite compensatory hyperinsulinemia (Chittezhath et al. 2019). As 12-weekold, $\mathrm{db} / \mathrm{db}$ islets were hyperplasic (but lean heterozygote siblings were not), we normalised the number of $\mathrm{TLR}^{+}$ stained cells with the total number of islet cells (for both lean and $\mathrm{db} / \mathrm{db}$ ) taking into consideration that $\mathrm{db} / \mathrm{db}$ islets had increased total islet cell number. The percentage of cells immunopositive for TLR1 increased by 2.9-fold, from $6.2 \%$ of cells being TLR $1^{+}$to $17.9 \%$ of cells being TLR1 ${ }^{+}$in $\mathrm{db} / \mathrm{db}$ islets $(P<0.01)$. The percentage of TLR2+ cells increased approximately 1.8 -fold, from $8.1 \%$ of cells within the healthy islet to $14.6 \%$ of cells within the obese diabetic islet $(P<0.05)$. TLR3 ${ }^{+}$and TLR4 ${ }^{+}$cell percentages increased from $2.8 \%$ to $7.8 \%(P<0.05)$ and $4.4 \%$ to $8.1 \%(P<0.05)$, respectively. The percentage of TLR9+ cells increased the highest among the different TLRs measured from $1.1 \%$ in the healthy islet to $6.5 \%$ in the obese islet (approx. six-fold increase) $(P<0.05)$ (Fig. $2 \mathrm{~A}$ and $\mathrm{B})$. Together, all measured TLRs within mouse islets increased in immunoreactivity suggesting that they were on a higher percentage of cells in the obese diabetic islet. 

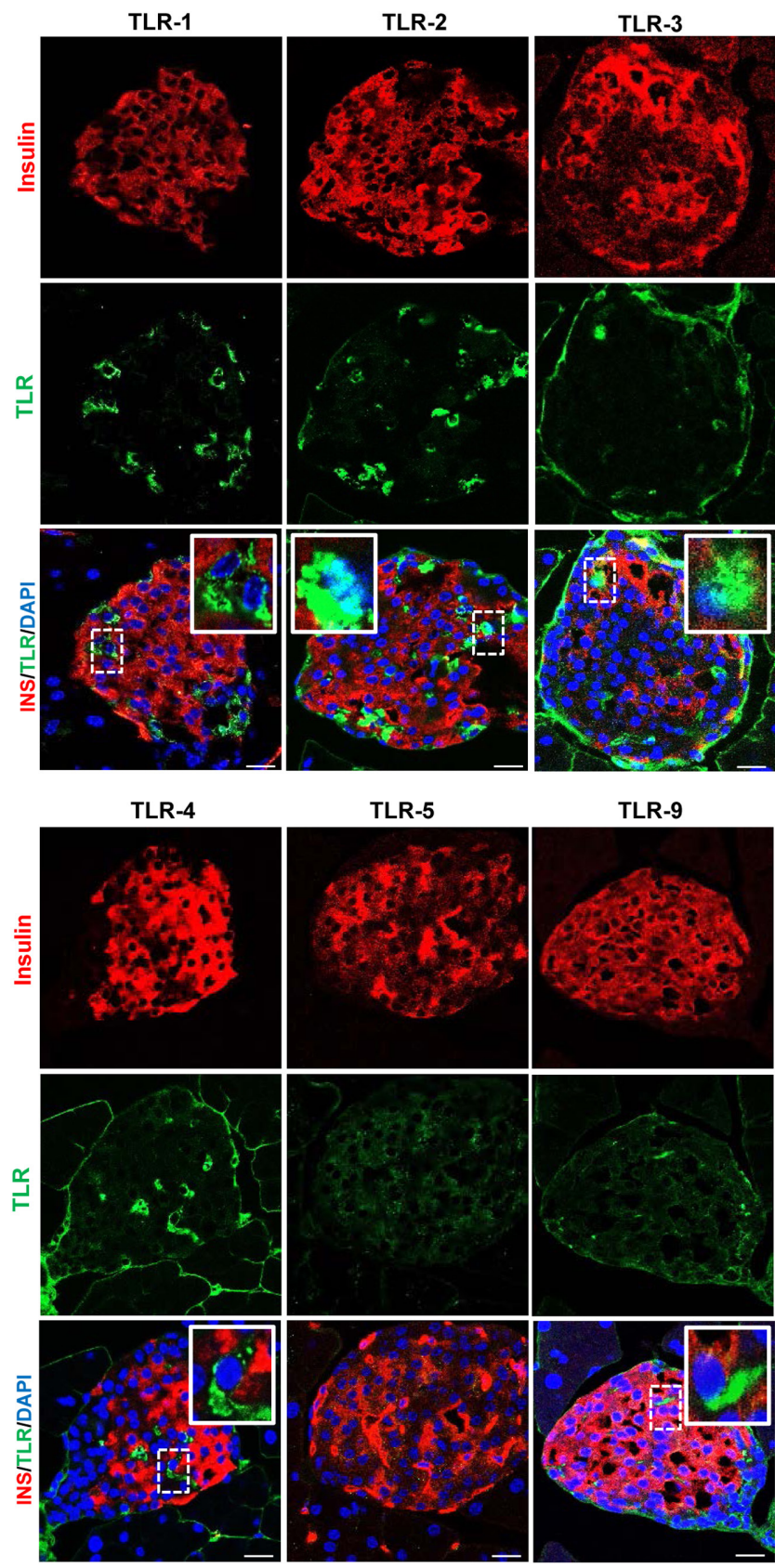

TLR-9
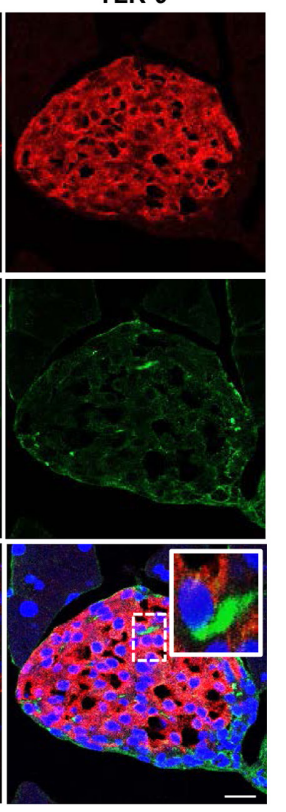

Figure 1

TLRs are immuno-positive in murine pancreatic islets but do not co-localise with $\beta$-cells. (A) Representative immunofluorescent images showing the presence of different TLRs (TLR1, 2, 3, 4, 5 and 9) in pancreatic islets from 12-week-old lean mice. Islets were immunolabelled with Insulin (red), TLRs (green) and DAPI (blue). Enlarged view of TLR signal on non- $\beta$-cells is shown in the insert (scale bar, $20 \mu \mathrm{m}$ ).

\section{TLRs expression within pancreatic islets is attributed to islet endothelial cells and macrophages}

Since all measured TLRs were absent on $\beta$-cells of both healthy and obese diabetic islets, we next sought to determine the islet cell-type that were immuno-positive for the different TLR proteins. TLR1 co-stained with CD31 but not CD68 suggesting that its presence within the islets were on endothelial cells and not macrophages (Fig. 3A and C). The percentage of TLR $1+C D 31+$ cells out of total islet cells significantly increased in diabetic islets (Fig. 3B and D), suggesting that a higher proportion of endothelial cells were TLR1 ${ }^{+}$in the hyperplasic $\mathrm{db} / \mathrm{db}$ islet. The percentage of TLR $1+C D 68^{+}$cells (already low to begin with) was not altered in diabetic islets. There remained TLR1+ cells that were neither $\mathrm{CD} 31^{+}$nor $\mathrm{CD} 68^{+}$cells (Fig. $3 \mathrm{~A}$ and C). In contrast, a majority of CD31+ cells were TLR2, TLR3, TLR4 and TLR9 positive and the percentages of these doublepositive cells were significantly increased in diabetic islets (Fig. 3A, B, C and D). TLR2, TLR3 and TLR4, but not TLR9, co-stained with both $\mathrm{CD} 31^{+}$and $\mathrm{CD} 68^{+}$cells suggesting that TLR2-4 were present on both endothelial cells and macrophages whilst TLR9 was confined to islet endothelial cells alone (Fig. 3A, B, C and D).

\section{Expansion of endothelial cells and macrophages contributed to increased TLR presence within diabetic islets}

The percentage of $\operatorname{TLR}_{\mathrm{x}}{ }^{+} / \mathrm{CD} 31^{+}$cells, $\mathrm{TLR}_{\mathrm{x}}{ }^{+} / \mathrm{CD} 68^{+}$cells over the total number of $\mathrm{TLR}_{\mathrm{x}}{ }^{+}$cells within each islet provides information on the relative cell distribution of different $\mathrm{TLR}^{+}$cells within an islet. Endothelial cells only accounted for approximately 12 and $30 \%$ of TLR1+ cells in lean and diabetic islets, respectively (Fig. 4A). As these other TLR1+ cells were consistently located close to the periphery of the mouse islet, we co-stained TLR1 with glucagon and found that TLR1+ cells actually co-localised with glucagon, suggesting TLR1 presence on islet $\alpha$-cells (in addition to endothelial cells) (Fig. 4A and B). In the obese diabetic islet, the increase in percentage of TLR1+ cells was partly due to the increase in islet endothelial (\% CD31+) cell number even though only a small percentage of endothelial cells were TLR1+ (Fig. 4A and D). Endothelial cells and macrophages accounted for most of TLR2 and TLR3 immunostaining within both lean and diabetic islets (Fig. 4A). While endothelial cells and macrophages accounted for approximately $90 \%$ of TLR4 ${ }^{+}$signal in diabetic islets, this percentage was lower (approximately 75\%) in healthy islets (Fig. 4A). Similar to TLR1, we reasoned that this merited additional attention and we co-stained sections for TLR4 and glucagon. However, the absence of co-localisation between TLR4 ${ }^{+}$ cells and glucagon ${ }^{+}$cells suggests that these "other (TLR4 ${ }^{+}$) cells" were not $\alpha$-cells (Fig. 4C). As both endothelial cells and macrophages were shown to increase in number 

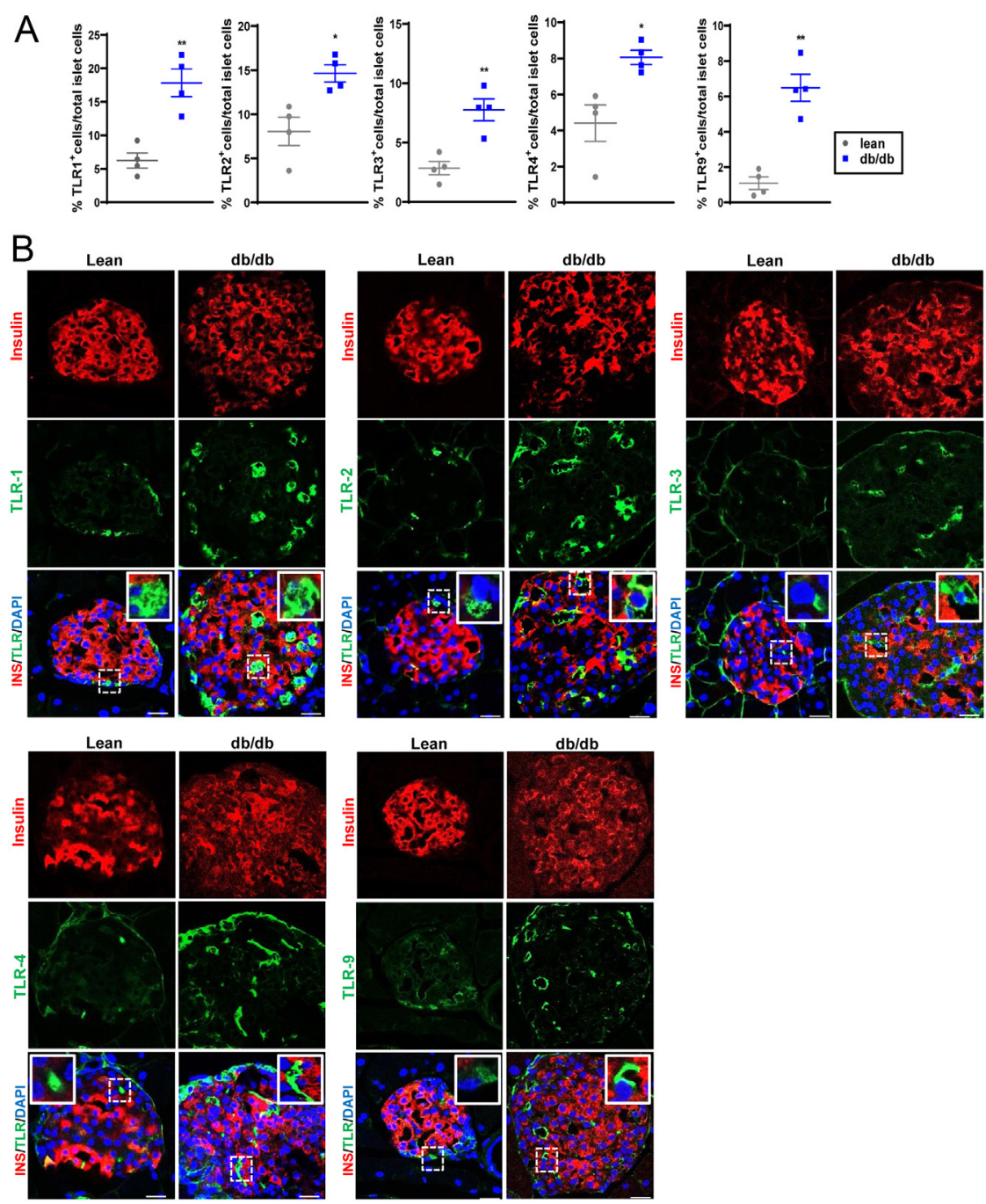

\begin{abstract}
Figure 2
TLRs are elevated in obese diabetic mouse pancreatic islets but remain absent in the $\beta$-cells. (A) Quantification of the different TLR+cells in the pancreatic islets of lean and $\mathrm{db} / \mathrm{db}$ islets represented as \% TLR+cells per total islet cells and (B) Representative immunofluorescence images showing the increased presence of different TLRs (TLR1, 2, 3, 4, and 9) in pancreatic islets from 12-week-old lean and $\mathrm{db} / \mathrm{db}$ islets. Islets were immunolabelled with Insulin (red), TLRs (green) and DAPI (blue). Enlarged view of TLR signal on non- $\beta$-cells is shown in the insert (scale bar, 20 $\mu \mathrm{m})$. Data presented as mean \pm S.E.M. $(n=4, \geq 12$ islets from four mice were analysed per group). $P$-values were calculated using unpaired Student's $t$-test, $* * P<0.01, * P<0.05$.
\end{abstract}

within 12 wk db/db islets (Chittezhath et al. 2019), we analysed double-positive cells $\left(\mathrm{TLR}_{\mathrm{x}}\right.$ with either CD31 or CD68) as a function of total $\mathrm{CD} 31^{+}$or $\mathrm{CD} 8^{+}$cells in lean and diabetic islets (Fig. 4D). The expansion of endothelial cells within $12 \mathrm{wk} \mathrm{db} / \mathrm{db}$ islets contributed to the increase in TLRs $2-4^{+}$and TLR9+ cell numbers within the diabetic islet with no significant differences when normalised to total endothelial cell number. However, there was a significant increase in TLR1 ${ }^{+} \mathrm{CD} 31^{+}$cell percentages after normalising to total islet $\mathrm{CD} 31^{+}$cells. This suggests that a higher proportion of endothelial cells were TLR1+ in diabetic islets compared with lean islets. In contrast, islet macrophage expansion likely contributed to the increased percentage of islet cells that are immunopositive for TLR2, and separately TLR3. For TLR4, we observed an approximately seven-fold increase in co-distribution of TLR4 $^{+}$and CD68 $^{+}$cells within diabetic islets compared to lean islets (31.1\% vs $4.7 \%$ ) (Fig. $4 \mathrm{~A})$. When compared to other TLRs, this large increase observed suggest that (c) 2020 Society for Endocrinology Published by Bioscientifica Ltd. Printed in Great Britain macrophage expansion in diabetic islets alone cannot be responsible for the higher TLR4 presence in diabetic islets. Indeed, there was still a significant increase in TLR4 ${ }^{+} \mathrm{CD} 68^{+}$ cell percentages after accounting for macrophage expansion (normalising to total islet $\mathrm{CD} 8^{+}$cells) in diabetic islets. This suggests that a higher proportion of macrophages were TLR4 ${ }^{+}$in diabetic islets compared with lean islets (Fig. 4D).

\section{Macrophages contribute to TLR4 signalling in healthy and diabetic islets}

Stimulation of TLR4 increased the inflammatory milieu of diabetic islets (Kim et al. 2007, Dasu et al. 2010, Nackiewicz et al. 2014, Westwell-Roper et al. 2014). Both islet endothelial cells and macrophages contributed significantly to TLR immunoreactivity within healthy and diabetic islets. To understand their relative contribution towards islet inflammation, we leveraged 
A
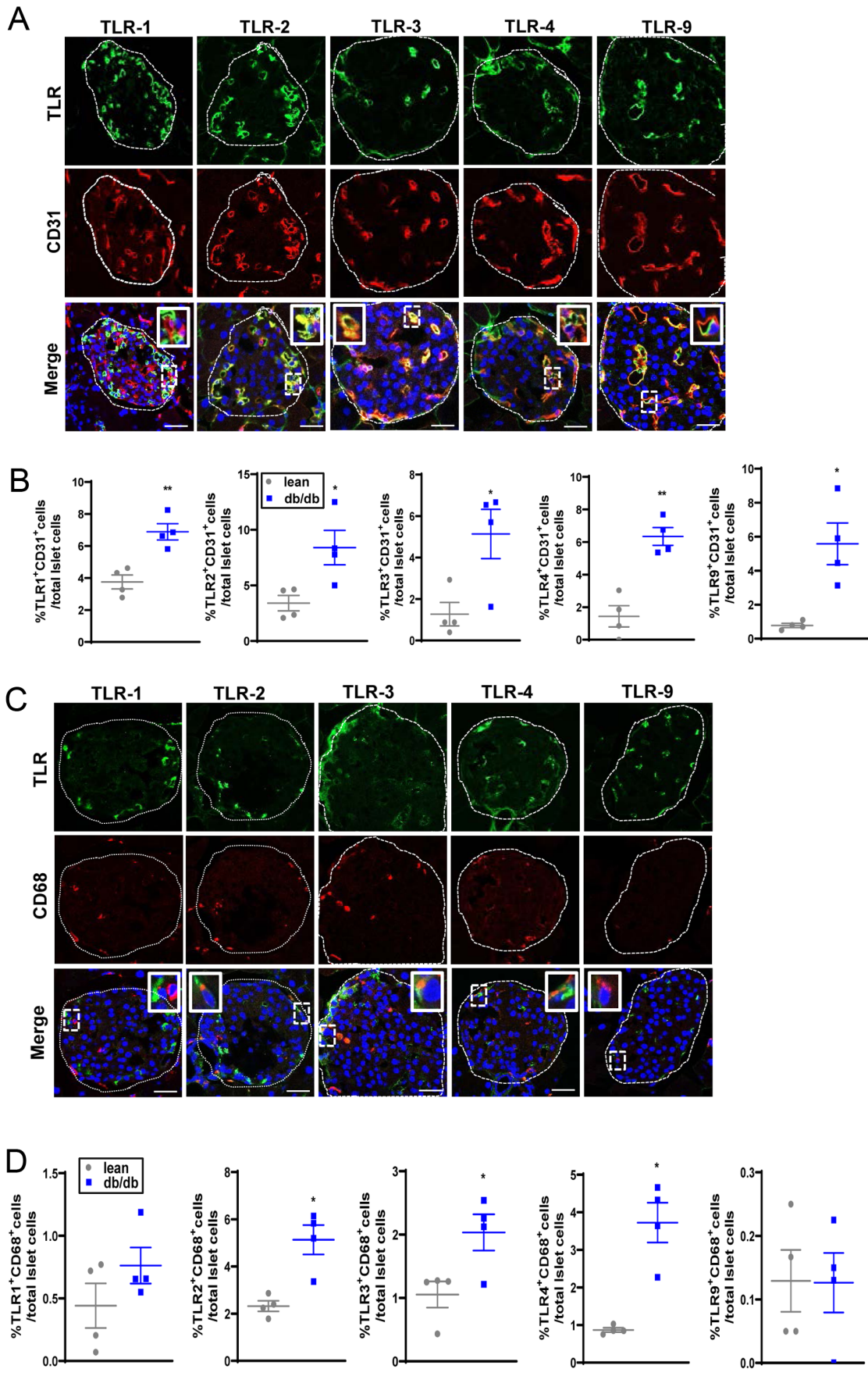

Figure 3

TLRs within pancreatic islets are attributed to islet endothelial cells and macrophages. (A)

Representative immunofluorescence images showing the increased presence of different TLRs (TLR1, 2, 3, 4, and 9) on endothelial (CD31+) cells in pancreatic islets from 12-week-old db/db islets compared to lean. Islets were immunolabelled with CD31 (red), TLRs (green) and DAPI (blue). Enlarged view of TLR signal on CD31+ cells is shown in the insert. (B) Quantification of the different TLR+CD31+cells in the pancreatic islets of lean and $\mathrm{db} / \mathrm{db}$ islets represented as \%TLR+CD31+ cells per total islet cells. (C) Representative immunofluorescence images showing the increased presence of different TLRs (TLR1, 2, 3, 4 and 9) on $\mathrm{CD}^{+} 8^{+}$macrophages in pancreatic islets from 12-week-old db/db islets. Islets were immunolabelled with CD68 (red), TLRs (green) and DAPI (blue). Enlarged view of TLR signal on $\mathrm{CD}^{+} 8^{+}$ cells is shown in the insert. (D) Quantification of the different $\mathrm{TLR}^{+} \mathrm{CD} 68^{+}$cells in the pancreatic islets of lean and $\mathrm{db} / \mathrm{db}$ islets represented as $\% \mathrm{TLR}^{+} \mathrm{CD} 68^{+}$cells per total islet cells (scale bar, $20 \mu \mathrm{m})$. Data presented as mean \pm S.E.M. $(n=4$, $\geq 12$ islets from four mice were analysed per group). $P$-values were calculated using unpaired Student's t-test, $* * P<0.01, * P<0.05$

on methods to deplete these cell types in islets ex vivo (Supplementary Fig. 2A). Previous reports using mice with labelled endothelial cells (Tie2-GFP) showed that islet endothelial cells migrated outwards, and were significantly reduced in number, after 3-4 days of culture (Nyqvist et al. 2005, 2011). Similarly, we observed that CD31 immunoreactivity was reduced by approximately 80\% in 3-day culturedlean and diabeticislets $(P<0.01)$ (Fig. $5 \mathrm{~A})$. Separately, blocking of colony stimulating factor 1 receptor (CSF1R) was shown to induce macrophage apoptosis (Carrero et al. 2017). Treatment of lean and diabetic islets with CSF1R blocking antibody AFS98, led to an approximate $90 \%$ depletion of $\mathrm{F} 4 / 80^{+}$macrophages $(P<0.01)$ (Fig. 5B). The percentage of TLR2 ${ }^{+}$and TLR4 ${ }^{+}$ cells were significantly reduced within both lean and obese diabetic islets following treatment with AFS98 $(P<0.01)$ (Supplementary Fig. 2B and C). The reduction in TLR2+ and TLR4+ staining seen within macrophagedepleted islets corroborate the above CD68 co-staining observations and perhaps also reinforce TLR2 and TLR4 

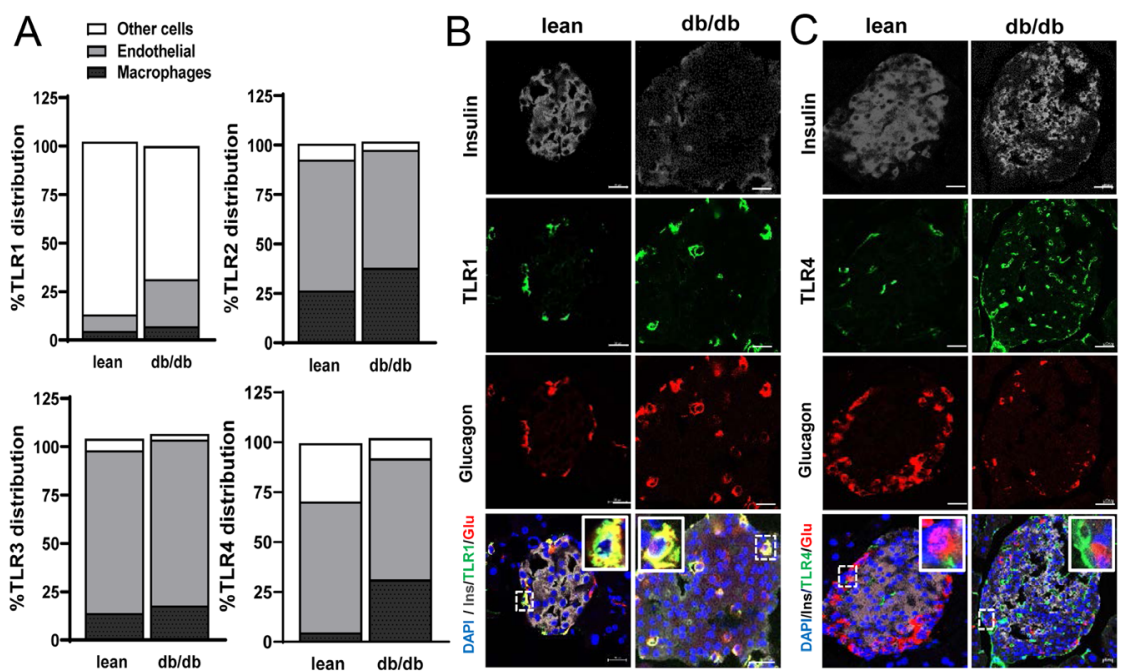

\section{Figure 4}

Distribution of the various TLRs in islet cells of healthy and $\mathrm{db} / \mathrm{db}$ mice. (A) Percentages were determined by calculating number of cells co-expressing $T L R_{x}$ with either CD31 (endothelial cell) or CD68 (macrophages) over the total number of specific $\operatorname{TLR}_{\mathrm{x}}$ expressing cells. Data presented as mean \pm S.E.M. $(n=4, \geq 12$ islets from four mice were analysed per group). TLR1, but not

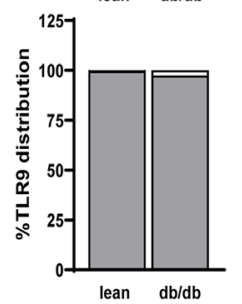

lean
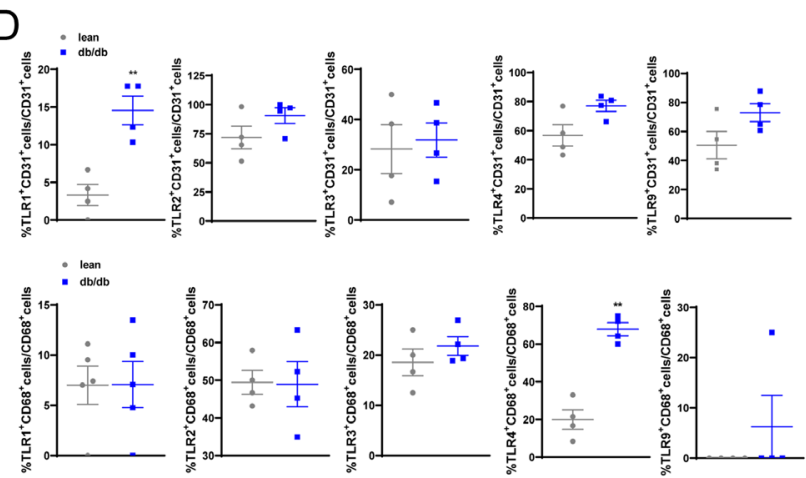
TLR4, is restricted mostly to $\alpha$-cells in lean and db/ $\mathrm{db}$ islets. Representative immunofluorescence images showing the expression of TLR1 (B) and TLR4 (C) on glucagon ${ }^{+} \alpha$-cells in pancreatic islets from both $\mathrm{db} / \mathrm{db}$ and lean islets. Islets were immunolabelled with insulin (grey), TLRs (green), glucagon (red) and DAPI (blue). Enlarged views of TLR1 and TLR signal on glucagon ${ }^{+} \alpha$-cells are shown in the inserts (scale bar, $20 \mu \mathrm{m}$ ). (D) Proportion of endothelial cells or macrophages that were $\mathrm{TLR}^{+}$in lean and diabetic islets. Data presented as mean \pm S.E.M. $(n=4, \geq 12$ islets from four mice were analysed per group).

antibody specificity. Treatment of TLR4 agonist, LPS, significantly increased the secretion of inflammatory cytokines IL-1 $\beta, \mathrm{TNF} \alpha, \mathrm{IL}-6, \mathrm{IL}-10$ and IL-18 in naïve (i.e. untreated) lean islets after a day of culture (day 1). This increase in secretion was significantly higher in obese diabetic islets compared to lean islets (Fig. 5C, D, E, F and G). Apart from suggested endogenous signals such as free fatty acids, IAPP, and ER stress, LPS also triggered inflammasome complex activation in islets leading to increased IL-1 $\beta$ and IL-18 secretion (Masters et al. 2010, Wen et al. 2011, Lebreton et al. 2018). In our hands, treatment of LPS significantly increased IL-1 $\beta$ secretion in day 3 islets for both lean and $\mathrm{db} /$ $\mathrm{db}$ islets. However, this increase was significantly abrogated in islets treated with AFS98, suggesting that islet macrophages contributed largely to islet TLR4-induced IL-1 $\beta$ secretion (Fig. 5C). Similarly, LPSinduced IL-18 secretion was significantly lower in obese diabetic islets devoid of macrophages (Fig. 5D). LPS treatment also enhanced the secretion of proinflammatory cytokines such as TNF $\alpha$, IL-6 and IL-10 in day 3 islets, but this increase was again significantly diminished in islets treated with AFS98 (Fig. 5E, F and $\mathrm{G})$. We found no significant change in islet cytokine secretion from days 1 to 3 untreated islets, ruling out the possible contribution of endothelial cell-mediated TLR signalling in pancreatic islets. Together these results suggest that though islet macrophages are fewer in number compared to endothelial cells, they are the major cell type responsible for TLR4-mediated increase in pro-inflammatory cytokine secretion, especially from diabetic islets.

\section{TLR4 transcripts are restricted to human islet macrophages}

Single-cell transcriptome datasets derived from published human islet datasets were analysed for the cell selectivity of TLR4 (Grun et al. 2016, Muraro et al. 2016, Segerstolpe et al. 2016, Lawlor et al. 2017). For human islet TLRs, most of which are lowly expressed at the single-cell gene expression level, only two TLRs were included in the top 2000 variable genes as determined by Seurat 

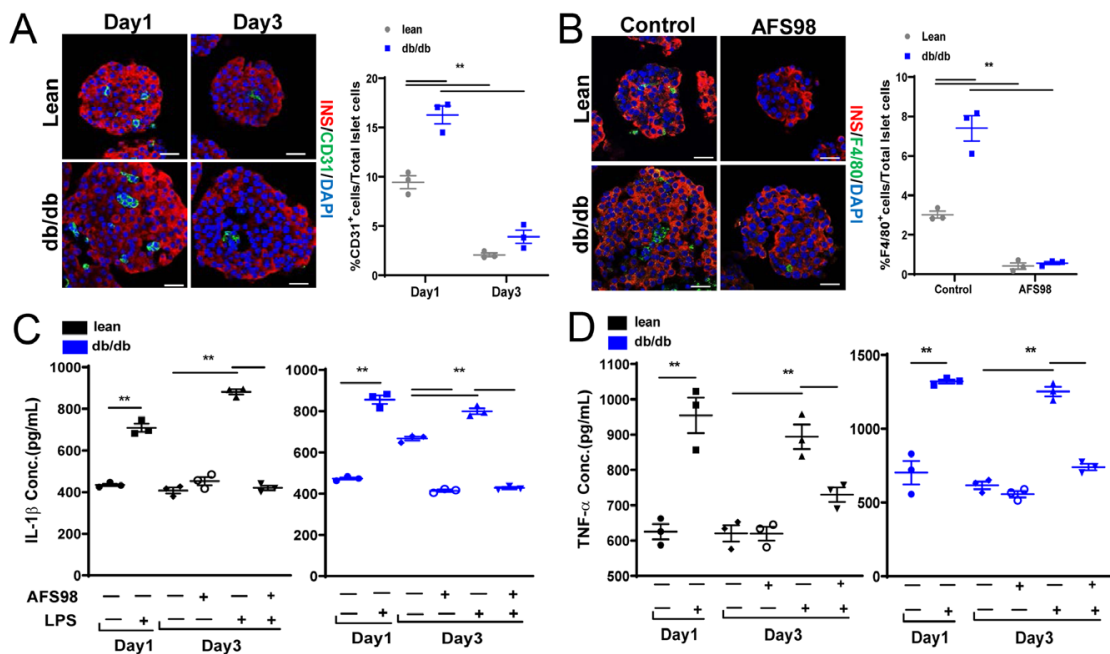

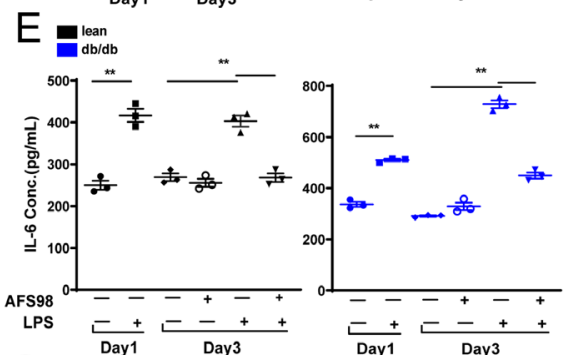

$F=$ lean

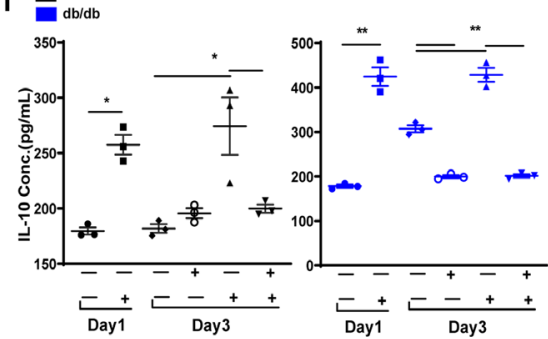

G
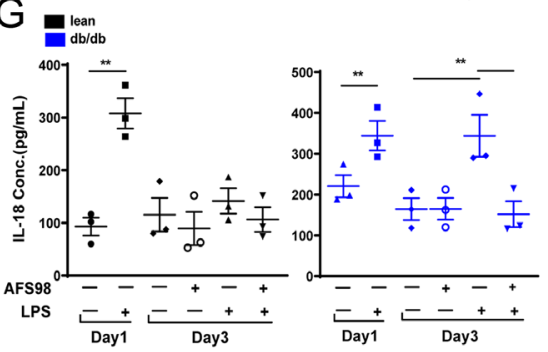

(https://satijalab.org/seurat/pancreas_integration_label _transfer.html). In our analysis, only TLR4 and TLR8 showed significant variation and cell-type specificity (islet macrophage) (Fig. 6). This suggests that first, human $\beta$-cells do not express TLRs, and second, human islet macrophages significantly contribute to the TLR4 expression pool within islets. Both of these observations corroborate our histological and functional studies using mouse islets. As a positive control, we show in the same datasets that PPy gene expression was restricted to the $\varepsilon$-cells of human islets, as expected (Supplementary Fig. 3). While other TLRs expressed in islet macrophages may not be statistically differentially expressed vs all other islet cells, it does appear that islet macrophages express numerically higher TLR1, TLR6, and TLR7 mRNA transcripts vs other islet cell types (Supplementary Fig 4). In addition, our analysis also showed no cell-type specificity for transcripts of other TLRs (such as TLR1 on $\alpha$-cells) (Supplementary Fig 4).
Figure 5

Macrophages contribute to TLR4 signalling in healthy and diabetic islets. (B) Representative immunofluorescence image showing depletion of $\mathrm{CD} 31^{+}$endothelial cells in lean and $\mathrm{db} / \mathrm{db}$ islets after 3 days of culture (left panel) and quantification of $\mathrm{CD} 31^{+}$cells (right panel). Insulin (red), CD31 (green), and DAPI (blue). (C)

Representative immunofluorescence image showing depletion of $\mathrm{F} 4 / 80^{+}$macrophages in lean and $\mathrm{db} / \mathrm{db}$ islets after AFS98 treatment (left panel) and quantification of $\mathrm{F} 4 / 80^{+}$macrophages (right panel). Insulin (red), F4/80 (green), and DAPI (blue). Data presented as mean \pm S.E.M. $(n=3, \geq 15$ islets in each group from three independent experiments). Analysis of cytokine production in the culture supernatants from lean and $\mathrm{db} / \mathrm{db}$ islets after macrophage depletion and LPS activation as indicated; (C) IL-1 $\beta$, (D) TNF- $\alpha$, (E) IL-6, (F) IL-10 and (G) IL-18. Lean islets (Left panel; white bars) and $\mathrm{db} / \mathrm{db}$ islets (right panel; black bars) (scale bar, $20 \mu \mathrm{m})$. Data presented as mean \pm S.E.M. ( $n=3$, three independent experiments). $P$-values were calculated using one-way ANOVA, $\star \star P<0.01$.

\section{Discussion}

In the present study, we analysed the expression pattern of various TLRs in lean and $\mathrm{db} / \mathrm{db}$ islets. We observed that most of the TLRs, apart from TLR5, were expressed in healthy islets and their presence increased in diabetic islets. Immunofluorescence analysis revealed that TLRs1-4 and TLR9 were not expressed in $\beta$-cells. TLRs2-4 were expressed in macrophages and endothelial cells. TLR1, in addition to endothelial cells, was also found to be present on $\alpha$-cells but not macrophages, an observation that has not been reported before. While this observation is likely real, further validation is required because first, RNASeq databases reveal very low expression of TLR1 in $\alpha$-cells, and second, $\alpha$-cells were noted to spuriously bind to IgG, more so than other islet cell types (Baskin 2015). TLR9 co-localised only with endothelial cells in lean and diabetic islets. Islet TLR3 was previously implicated in viral dsRNA-mediated $\beta$-cell apoptosis in T1D (Wen et al. 2004, 


\begin{tabular}{l|l|l|l|l|}
$\begin{array}{l}\text { Journal of } \\
\text { Endocrinology }\end{array}$ & M Chittezhath et al. & $\begin{array}{l}\text { Islet TLR cell-restriction and } \\
\text { signalling }\end{array}$ & $\mathbf{2 4 7 : 1}$ & $\mathbf{9 6}$ \\
\hline
\end{tabular}
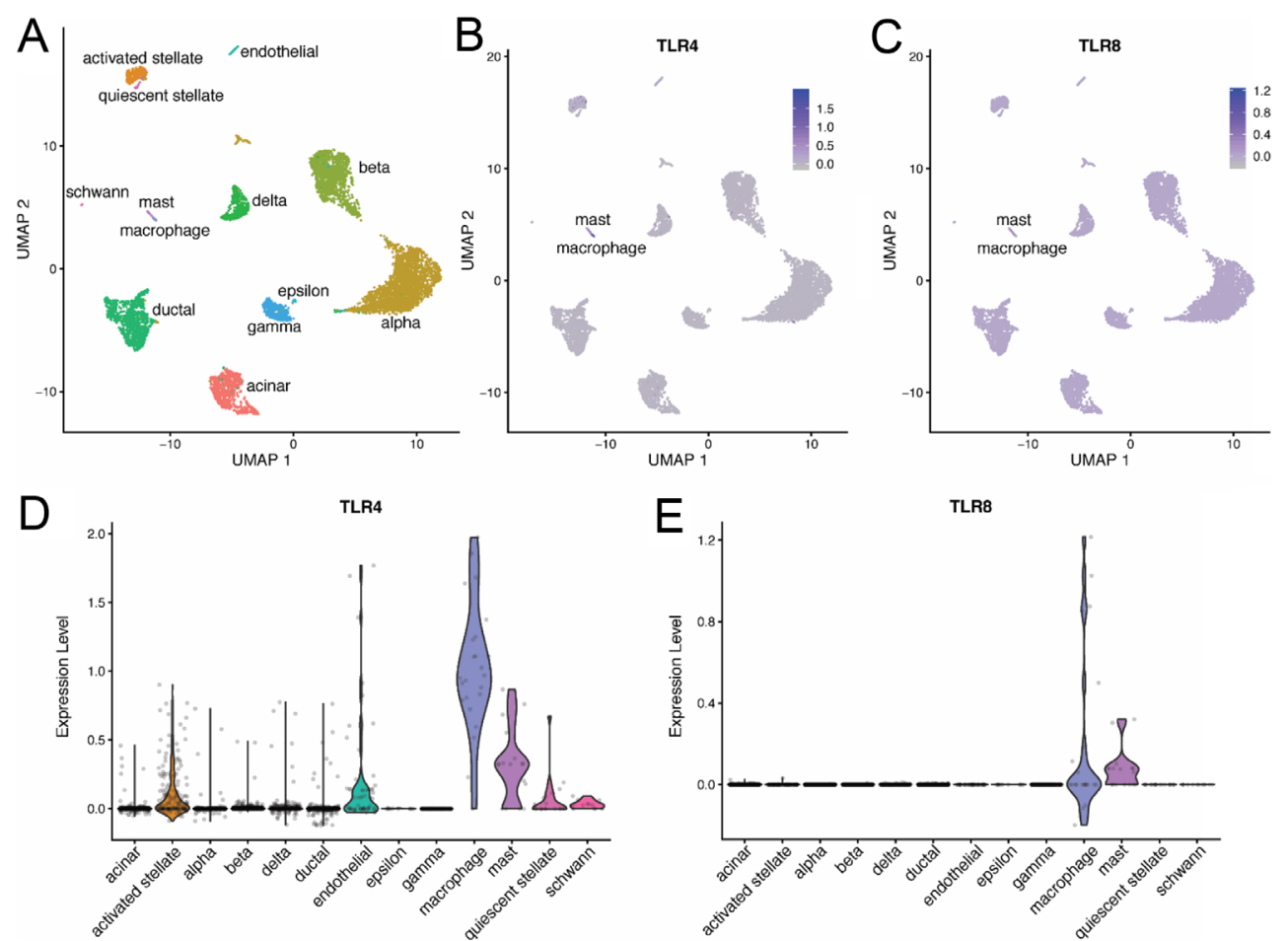

\section{Figure 6}

TLR4 expression by single-cell islet transcriptomic analysis shows restriction to human islet macrophage. (A) Uniform manifold approximation and projection (UMAP) of the single-cell transcriptome, coloured by cell type, from four single cell datasets. (B) UMAP of the single-cell transcriptome, coloured by TLR4 expression. (C) UMAP of the single-cell transcriptome coloured by TLR8 expression. (D) Violin plots of normalised expression of TLR4 by cell type. (E) Violin plots of normalised expression of TLR8 by cell type.

Rasschaert et al. 2005, Dogusan et al. 2008), and separately in the control of insulin secretion during T2D (Strodthoff et al. 2015). However, none of these reports had pointed specifically towards $\beta$-cell TLR3 expression. Consistent with this, we found that TLR3 did not co-localise with $\beta$-cells but rather on islet endothelial cells, and to a lesser extent on islet macrophages, in both healthy and obese diabetic islets. We add a cautionary note that most of the above conclusions were drawn from immunofluorescence observations. Noteworthy, whilst all TLR antibodies used were knockout validated (Ilvesaro et al. 2008, Stridh et al. 2011, Uthaya Kumar et al. 2016, Regel et al. 2019), the TLR5 antibody was not. However, previous studies had used this same antibody for detecting TLR5 in various tissues (Ha et al. 2008, Uchida et al. 2014).

TLR4 is strongly and consistently linked with $\beta$-cell dysfunction. However, TLR4 presence on $\beta$-cells remained controversial. Previous reports allude to TLR4 co-localising with human and mouse primary $\beta$-cells (Garay-Malpartida et al. 2011, Li et al. 2012), and TLR4 deficient mice had altered $\beta$-cell responses when placed on a high fat diet (Li et al. 2013, He et al. 2018). NRLP3 inflammasome complex activation, downstream of TLR4 signalling, did not affect
IL-1 $\beta$ production and secretion from $\beta$-cells in culture (Wali et al. 2014). While NLRP3 activation induced the increase in IL-1 $\beta$ production and secretion, this effect was seen in whole islets and not in isolated $\beta$-cells (Lebreton et al. 2018). Taken as a whole, these seemingly contradictory observations, do suggest that while islet TLR4 signalling is important, it does not take place in $\beta$-cells. This concept of non- $\beta$-cell autonomous TLR4 signalling was alluded to previously (Nackiewicz et al. 2014) and we confirm this.

Our immunofluorescence results showed that TLR4 co-localised with islet endothelial cells and a subset of islet macrophages. The expansion of both endothelial cells and macrophages in 12-week-old diabetic $(\mathrm{db} / \mathrm{db})$ islets contributed to the increased presence of TLR4 in diabetic islets. Islet macrophage expansion was also noted in mice fed with a high-fat diet (Ying et al. 2019) and separately in $\mathrm{db} / \mathrm{db}$ mice on a different background (BKS $\mathrm{db}$ ) compared to ours (B6 db) (Nackiewicz et al. 2020). The increase in islet macrophages were suggested to be both a boon (through PDGF and IGF1 mediated signalling) and bane (through cell contact-dependent mechanisms) for $\beta$-cell function in these mice. Herein, we value add by showing that beyond the mere increase in absolute numbers, 
we observed a higher proportion of islet macrophages that were TLR4+ in diabetic islets. TLR4 activation contributes to islet inflammatory milieu and this may perhaps be another mechanism promotes $\beta$-cell dysfunction. We depleted either endothelial cell or islet macrophage ex vivo to delineate their respective contributions towards TLR4mediated cytokine secretion. We found that depletion of islet macrophages, but not endothelial cells, significantly downregulated the LPS-induced secretion of inflammatory cytokines IL-1 $\beta$, TNF $\alpha$, IL-6, IL-10 and IL-18. This effect was more pronounced in $\mathrm{db} / \mathrm{db}$ islets suggesting that though few in absolute numbers, islet macrophages play a significant role in TLR4-mediated inflammatory cytokine secretion, especially within the $\mathrm{db} / \mathrm{db}$ islets. The role of islet macrophages towards TLR4-induced IL- $1 \beta$ secretion was previously reported in healthy mouse and human islets (Nackiewicz et al. 2014). This study also showed that islet macrophages remained the largest contributor to TLR4 signalling within diabetic islets. We found that islet macrophages were responsible for TLR4 ligand-mediated IL1 $\beta$ and IL18 secretion, and this warrants further studies on the role of inflammasome complex activation specifically in islet macrophages. Consistent with the mouse islet cell-type specificity of TLR expression, human islet single-cell transcriptome analysis suggests that islet macrophages, but not $\beta$-cells, significantly contributed to TLR4 and TLR8 transcript pool within human islets. This is in direct contrast to what was reported earlier (Helminen et al. 2017). Noteworthy, single-cell RNA-sequencing has its limitations. Cell dissociation and sorting steps may introduce artifacts that affect downstream analysis. Nevertheless, TLR4 signalling was reported to be enhanced in islets from obese donors (He et al. 2019). However, further validation is required to link this observation to increased human islet macrophage numbers.

During diabetes, the impact of TLRs within peripheral tissues is clear but its contribution and mechanism within pancreatic islets remain relatively unknown. Activation of TLRs in peripheral tissues exacerbated insulin resistance, with TLR2 and TLR4 mediating metabolic (dys)regulation during T2D (Shi et al. 2006, Konner \& Bruning 2011, Donath 2014). Loss of either TLR2 or TLR4 in High Fat Diet (HFD) fed mice reduced systemic inflammation and improve insulin sensitivity (Himes \& Smith 2010, Jia et al. 2014, Vila et al. 2014, Razolli et al. 2015) while diabetic subjects had increased TLR2 and TLR4 expression in circulating monocytes (Dasu et al. 2010, Devaraj et al. 2011). Furthermore, whole-body loss of both TLR2 and TLR4 increased HFD-induced $\beta$-cell replication and enhanced compensatory hyperinsulinemia, suggesting that both
TLRs negatively affected islet remodelling and glucose homeostasis (Ji et al. 2019). When it came to pancreatic islets, TLR2, TRL3 and TLR4 were shown to directly contribute to autoimmune diabetes and allogenic islet transplant rejection (Wen et al. 2004, Goldberg et al. 2007, Dogusan et al. 2008, Krüger et al. 2010). Consistent with these reports, our immunostaining results clearly showed a significant increase in the expression of TLR1-4 and TLR9 in the islets from $\mathrm{db} / \mathrm{db}$ mice but these TLRs were not expressed on $\beta$-cells. Hence, the effect of either TLR2, TLR3 or TLR4 signalling on $\beta$-cells, diabetic or otherwise, were unlikely autocrine-mediated. TLRs, specifically TLR4, are predominantly expressed on innate immune cells such as tissue-associated macrophages with cell numbers increasing obesity and diabetes prolonged (Kraakman et al. 2014). Consistent with these observations, we showed a significant increase in CD68 ${ }^{+}$cells co-expressing TLR2, TLR3 and TLR4 within diabetic islets. We also observed a higher proportion of macrophages that were immuno-positive for TLR4. We showed through islet cell depletion experiments, that islet macrophages were a significant contributor to TLR4 signalling within islets. Elegant co-culture experiments involving diabetic macrophages and $\beta$-cells, showed that TLR4 contributed significantly to $\beta$-cell apoptosis (Cucak et al. 2014). This supports our findings that macrophages are an integral contributor to TLR4 signalling within islets.

In the early compensatory stages of diabetes, islet vasculature needs to increase to perfuse the expanding $\beta$-cell mass accounted for by the increase in islet endothelial cells (Brissova et al. 2006, Chittezhath et al. 2019). In line with this, and with the knowledge that TLRs are expressed on islet endothelial cells, our results clearly showed a significant increase in TLR1, 2, 3, 4 and 9 expressing $\mathrm{CD} 1^{+}$cells within obese diabetic islets. TLR2 and TLR4 were shown to induce inflammation in diabetic coronary artery endothelial cells, suggesting that islet endothelial cells may similarly contribute to TLR2 and/ or TLR4 signalling during T2D (Li et al. 2010). TLR2 and TLR4 were also reported to play a critical role in inflammation-associated angiogenesis (Li \& Sun 2007, de Groot et al. 2011). While our results demonstrated that various TLRs were present on pancreatic islet endothelial cells, the islet macrophage, and not the endothelial cell, was the key cell-type responsible for mediating the TLR response (at least for TLR4). Ex vivo cell depletion experiments showed that a reduction of islet endothelial cells had no significant impact on basal pro-inflammatory cytokine secretion of lean and diabetic islets. In contrast, LPS-induced pro-inflammatory cytokine secretion from islets was significantly reduced 
upon macrophage depletion - an effect that was more pronounced in diabetic islets. An analysis of published human islet single-cell RNAseq databases showed that only TLR4 and TLR8 showed significant restriction to islet macrophages. None of the other TLRs showed celltype specificity and none were significantly expressed in $\beta$-cells. However, islet macrophage subtype contribution (resident vs monocytic-derived) and its downstream inflammasome complex activation during TLR4 mediated $\beta$-cell dysfunction in both mouse and human islets warrant further investigation.

In conclusion, our study attempted to provide a more complete picture of TLR presence in various cells of the pancreatic islet. TLRs were mostly present on islet endothelial cells and islet macrophages, except for TLR1 being on $\alpha$-cells and TLR9 only on endothelial cells. Importantly, $\beta$-cells were not immuno-positive for TLRs1-5 and 9. In addition, increased TLR presence in $\mathrm{db} / \mathrm{db}$ islets were largely driven by endothelial cell and macrophage cell expansion. For TLR4, a greater proportion of macrophages displayed TLR4 positivity in diabetic islets. While TLR4 signalling increased islet cytokine secretion, this was largely mediated by islet macrophages and not endothelial cells of diabetic islets.

\section{Supplementary materials}

This is linked to the online version of the paper at https://doi.org/10.1530/ JOE-20-0131.

\section{Declaration of interest}

The authors declare that there is no conflict of interest that could be perceived as prejudicing the impartiality of the research reported.

\section{Funding}

This work is supported by the Singapore Ministry of Education under its Singapore Ministry of Education Academic Research Fund Tier 1 and Tier 2 (MOE2017-T2-1-038, 1T1-02/04, 2017-T1-001-220) to Y A. This work is also partly supported by the LKCMedicine Healthcare Research Fund (Diabetes Research), established through the generous support of alumni of Nanyang Technological University Singapore. S R L is supported by Nanyang Technological University Singapore, Nanyang Assistant Professorship Start-Up Grant. C M M W is additionally supported by the Interdisciplinary Graduate Scholarship, Nanyang Technological University Singapore.

\section{Author contribution statement}

Y A conceptualised and analysed the study. M C wrote the manuscript. M C and C M M W, V S Y T and C M performed and analysed the experiments. S R L analysed TLR expression using published human islet single-cell RNASeq datasets. Y A critically edited the manuscript and is responsible for the study.

\section{References}

Akira S, Takeda K \& Kaisho T 2001 Toll-like receptors: critical proteins linking innate and acquired immunity. Nature Immunology 2 675-680. (https://doi.org/10.1038/90609)

(c) 2020 Society for Endocrinology Published by Bioscientifica Ltd. Printed in Great Britain
Baskin DG 2015 A historical perspective on the identification of cell types in pancreatic islets of Langerhans by staining and histochemical techniques. Journal of Histochemistry and Cytochemistry 63 543-558. (https://doi.org/10.1369/0022155415589119)

Brissova M, Shostak A, Shiota M, Wiebe PO, Poffenberger G, Kantz J, Chen Z, Carr C, Jerome WG, Chen J, et al. 2006 Pancreatic islet production of vascular endothelial growth factor - a is essential for islet vascularization, revascularization, and function. Diabetes $\mathbf{5 5}$ 2974-2985. (https://doi.org/10.2337/db06-0690)

Burrows MP, Volchkov P, Kobayashi KS \& Chervonsky AV 2015 Microbiota regulates type 1 diabetes through toll-like receptors. PNAS 112 9973-9977. (https://doi.org/10.1073/pnas.1508740112)

Carrero JA, Mccarthy DP, Ferris ST, Wan X, Hu H, Zinselmeyer BH, Vomund AN \& Unanue ER 2017 Resident macrophages of pancreatic islets have a seminal role in the initiation of autoimmune diabetes of NOD mice. PNAS 114 E10418-E10427. (https://doi.org/10.1073/ pnas.1713543114)

Carter JD, Dula SB, Corbin KL, Wu R \& Nunemaker CS 2009 A practical guide to rodent islet isolation and assessment. Biological Procedures Online 11 3-31. (https://doi.org/10.1007/s12575-009-9021-0)

Chittezhath M, Gunaseelan D, Zheng X, Hasan R, Tay VSY, Lim ST, Wang X, Berggren PO, Bornstein S, Boehm B, et al. 2019 Islet macrophages are associated with islet vascular remodeling and compensatory hyperinsulinemia during diabetes. American Journal of Physiology: Endocrinology and Metabolism 317 E1108-E1120. (https:// doi.org/10.1152/ajpendo.00248.2019)

Cucak H, Mayer C, Tonnesen M, Thomsen LH, Grunnet LG \& Rosendahl A 2014 Macrophage contact dependent and independent TLR4 mechanisms induce beta-cell dysfunction and apoptosis in a mouse model of type 2 diabetes. PLOS ONE 9 e90685. (https://doi. org/10.1371/journal.pone.0090685)

Dasu MR, Devaraj S, Park S \& Jialal I 2010 Increased toll-like receptor (TLR) activation and TLR ligands in recently diagnosed type 2 diabetic subjects. Diabetes Care 33 861-868. (https://doi.org/10.2337/dc09-1799)

De Groot D, Hoefer IE, Grundmann S, Schoneveld A, Haverslag RT, Van Keulen JK, Bot PT, Timmers L, Piek JJ, Pasterkamp G, et al. 2011 Arteriogenesis requires toll-like receptor 2 and 4 expression in bonemarrow derived cells. Journal of Molecular and Cellular Cardiology $\mathbf{5 0}$ 25-32. (https://doi.org/10.1016/j.yjmcc.2010.08.006)

Devaraj S, Dasu MR, Rockwood J, Winter W, Griffen SC \& Jialal I 2008 Increased toll-like receptor (TLR) 2 and TLR4 expression in monocytes from patients with type 1 diabetes: further evidence of a proinflammatory state. Journal of Clinical Endocrinology and Metabolism 93 578-583. (https://doi.org/10.1210/jc.2007-2185)

Devaraj S, Jialal I, Yun JM \& Bremer A 2011 Demonstration of increased toll-like receptor 2 and toll-like receptor 4 expression in monocytes of type 1 diabetes mellitus patients with microvascular complications. Metabolism: Clinical and Experimental 60 256-259. (https://doi. org/10.1016/j.metabol.2010.01.005)

Dogusan Z, Garcia M, Flamez D, Alexopoulou L, Goldman M, Gysemans C, Mathieu C, Libert C, Eizirik DL \& Rasschaert J 2008 Double-stranded RNA induces pancreatic beta-cell apoptosis by activation of the toll-like receptor 3 and interferon regulatory factor 3 pathways. Diabetes $\mathbf{5 7}$ 1236-1245. (https://doi.org/10.2337/db07-0844)

Donath MY 2014 Targeting inflammation in the treatment of type 2 diabetes: time to start. Nature Reviews: Drug Discovery 13 465-476. (https://doi.org/10.1038/nrd4275)

Garay-Malpartida HM, Mourao RF, Mantovani M, Santos IA, Sogayar MC \& Goldberg AC 2011 Toll-like receptor 4 (TLR4) expression in human And murine pancreatic beta-cells affects cell viability and insulin homeostasis. BMC Immunology 12 18. (https://doi.org/10.1186/1471-2172-12-18)

Goldberg A, Parolini M, Chin BY, Czismadia E, Otterbein LE, Bach FH \& Wang H 2007 Toll-like receptor 4 suppression leads to islet allograft survival. FASEB Journal 21 2840-2848. (https://doi.org/10.1096/fj.067910com)

Grun D, Muraro MJ, Boisset JC, Wiebrands K, Lyubimova A, Dharmadhikari G, Van Den Born M, Van Es J, Jansen E, Clevers H, 
et al. 2016 De novo prediction of stem cell identity using singlecell transcriptome data. Cell Stem Cell 19 266-277. (https://doi. org/10.1016/j.stem.2016.05.010)

Ha H, Lee JH, Kim HN, Kwak HB, Kim HM, Lee SE, Rhee JH, Kim HH \& Lee ZH 2008 Stimulation by TLR5 modulates osteoclast differentiation through STAT1/IFN-beta. Journal of Immunology 180 1382-1389. (https://doi.org/10.4049/jimmunol.180.3.1382)

He W, Yuan T, Choezom D, Hunkler H, Annamalai K, Lupse B \& Maedler K 2018 Ageing potentiates diet-induced glucose intolerance, beta-cell failure and tissue inflammation through TLR4. Scientific Reports 8 2767. (https://doi.org/10.1038/s41598-018-20909-w)

He W, Rebello O, Savino R, Terracciano R, Schuster-Klein C, Guardiola B \& Maedler K 2019 TLR4 triggered complex inflammation in human pancreatic islets. Biochimica et Biophysica Acta: Molecular Basis of Disease 1865 86-97. (https://doi.org/10.1016/j.bbadis.2018.09.030)

Helminen O, Huhta H, Kauppila JH, Lehenkari PP, Saarnio J \& Karttunen TJ 2017 Localization of nucleic acid-sensing toll-like receptors in human and mouse pancreas. APMIS 125 85-92. (https:// doi.org/10.1111/apm.12632)

Himes RW \& Smith CW 2010 Tlr2 is critical for diet-induced metabolic syndrome in a murine model. FASEB Journal 24 731-739. (https://doi. org/10.1096/fj.09-141929)

Ilvesaro JM, Merrell MA, Li L, Wakchoure S, Graves D, Brooks S, Rahko E, Jukkola-Vuorinen A, Vuopala KS, Harris KW, et al. 2008 Toll-like receptor 9 mediates $\mathrm{CpG}$ oligonucleotide-induced cellular invasion. Molecular Cancer Research 6 1534-1543. (https://doi.org/10.1158/15417786.MCR-07-2005)

Ji Y, Sun S, Shrestha N, Darragh LB, Shirakawa J, Xing Y, He Y, Carboneau BA, Kim H, An D, et al. 2019 Toll-like receptors TLR2 and TLR4 block the replication of pancreatic beta cells in diet-induced obesity. Nature Immunology 20 677-686. (https://doi.org/10.1038/ s41590-019-0396-z)

Jia L, Vianna CR, Fukuda M, Berglund ED, Liu C, Tao C, Sun K, Liu T, Harper MJ, Lee CE, et al. 2014 Hepatocyte toll-like receptor 4 regulates obesity-induced inflammation and insulin resistance. Nature Communications 5 3878. (https://doi.org/10.1038/ncomms4878)

Kim F, Pham M, Luttrell I, Bannerman DD, Tupper J, Thaler J, Hawn TR, Raines EW \& Schwartz MW 2007 Toll-like receptor-4 mediates vascular inflammation and insulin resistance in diet-induced obesity. Circulation Research 100 1589-1596. (https://doi.org/10.1161/ CIRCRESAHA.106.142851)

Konner AC \& Bruning JC 2011 Toll-Like receptors: linking inflammation to metabolism. Trends in Endocrinology and Metabolism 22 16-23. (https://doi.org/10.1016/j.tem.2010.08.007)

Kraakman MJ, Murphy AJ, Jandeleit-Dahm K \& Kammoun HL 2014 Macrophage polarization in obesity and type 2 diabetes: weighing down our understanding of macrophage function? Frontiers in Immunology 5 470. (https://doi.org/10.3389/fimmu.2014.00470)

Krüger B, Yin N, Zhang N, Yadav A, Coward W, Lal G, Zang W, S Heeger P, Bromberg JS, Murphy B, et al. 2010 Islet-expressed TLR2 and TLR4 sense injury and mediate early graft failure after transplantation. European Journal of Immunology $\mathbf{4 0} 2914-2924$. (https://doi. org/10.1002/eji.201040601)

Lawlor N, George J, Bolisetty M, Kursawe R, Sun L, Sivakamasundari V, Kycia I, Robson P \& Stitzel ML 2017 Single-cell transcriptomes identify human islet cell signatures and reveal cell-type-specific expression changes in type 2 diabetes. Genome Research 27 208-222. (https://doi.org/10.1101/gr.212720.116)

Lebreton F, Berishvili E, Parnaud G, Rouget C, Bosco D, Berney T \& Lavallard V 2018 NLRP3 inflammasome is expressed and regulated in human islets. Cell Death and Disease 9 726. (https://doi.org/10.1038/ s41419-018-0764-x)

Lee MS, Kim DH, Lee JC, Kim S \& Kim HS 2011 Role of TLR2 in the pathogenesis of autoimmune diabetes and its therapeutic implication. Diabetes/Metabolism Research and Reviews 27 797-801. (https://doi. org/10.1002/dmrr.1231)
Li H \& Sun B 2007 Toll-like receptor 4 in atherosclerosis. Journal of Cellular and Molecular Medicine 11 88-95. (https://doi.org/10.1111/ j.1582-4934.2007.00011.x)

Li J, Jin C, Cleveland JC, Ao L, Xu D, Fullerton DA \& Meng X 2010 Enhanced inflammatory responses to toll-like receptor $2 / 4$ stimulation in type 1 diabetic coronary artery endothelial cells: the effect of insulin. Cardiovascular Diabetology 9 90. (https://doi. org/10.1186/1475-2840-9-90)

Li M, Song L, Gao X, Chang W \& Qin X 2012 Toll-like receptor 4 on islet beta cells senses expression changes in high-mobility group box 1 and contributes to the initiation of type 1 diabetes. Experimental and Molecular Medicine 44 260-267. (https://doi.org/10.3858/emm.2012.44.4.021)

Li J, Chen L, Zhang Y, Zhang WJ, Xu W, Qin Y, Xu J \& Zou D 2013 TLR4 is required for the obesity-induced pancreatic beta cell dysfunction. Acta Biochimica et Biophysica Sinica 45 1030-1038. (https://doi. org/10.1093/abbs/gmt092)

Masters SL, Dunne A, Subramanian SL, Hull RL, Tannahill GM, Sharp FA, Becker C, Franchi L, Yoshihara E, Chen Z, et al. 2010 Activation of the NLRP3 inflammasome by islet amyloid polypeptide provides a mechanism for enhanced IL-1beta in type 2 diabetes. Nature Immunology 11 897-904. (https://doi.org/10.1038/ni.1935)

Muraro MJ, Dharmadhikari G, Grun D, Groen N, Dielen T, Jansen E, Van Gurp L, Engelse MA, Carlotti F, De Koning EJ, et al. 2016 A single-cell transcriptome atlas of the human pancreas. Cell Systems 3 385.e3-394. e3. (https://doi.org/10.1016/j.cels.2016.09.002)

Nackiewicz D, Dan M, He W, Kim R, Salmi A, Rutti S, Westwell-Roper C, Cunningham A, Speck M, Schuster-Klein C, et al. 2014 TLR2/6 and TLR4-activated macrophages contribute to islet inflammation and impair beta cell insulin gene expression via IL-1 and IL-6. Diabetologia 57 1645-1654. (https://doi.org/10.1007/s00125-0143249-1)

Nackiewicz D, Dan M, Speck M, Chow SZ, Chen YC, Pospisilik JA, Verchere CB \& Ehses JA 2020 Islet macrophages shift to a reparative state following pancreatic beta-cell death and are a major source of islet insulin-like growth factor-1. iScience 23 100775. (https://doi. org/10.1016/j.isci.2019.100775)

Nyqvist D, Kohler M, Wahlstedt H \& Berggren PO 2005 Donor islet endothelial cells participate in formation of functional vessels within pancreatic islet grafts. Diabetes 54 2287-2293. (https://doi. org/10.2337/diabetes.54.8.2287)

Nyqvist D, Speier S, Rodriguez-Diaz R, Molano RD, Lipovsek S, Rupnik M, Dicker A, Ilegems E, Zahr-Akrawi E, Molina J, et al. 2011 Donor islet endothelial cells in pancreatic islet revascularization. Diabetes $\mathbf{6 0}$ 2571-2577. (https://doi.org/10.2337/db10-1711)

Rasschaert J, Ladriere L, Urbain M, Dogusan Z, Katabua B, Sato S, Akira S, Gysemans C, Mathieu C \& Eizirik DL 2005 Toll-like receptor 3 and STAT-1 contribute to double-stranded RNA+ interferon-gamma-induced apoptosis in primary pancreatic beta-cells. Journal of Biological Chemistry 280 33984-33991. (https://doi.org/10.1074/jbc.M502213200)

Razolli DS, Moraes JC, Morari J, Moura RF, Vinolo MA \& Velloso LA 2015 TLR4 expression in bone marrow-derived cells is both necessary and sufficient to produce the insulin resistance phenotype in diet-induced obesity. Endocrinology 156 103-113. (https://doi.org/10.1210/en.20141552)

Regel I, Raulefs S, Benitz S, Mihaljevic C, Rieder S, Leinenkugel G, Steiger K, Schlitter AM, Esposito I, Mayerle J, et al. 2019 Loss of TLR3 and its downstream signaling accelerates acinar cell damage in the acute phase of pancreatitis. Pancreatology 19 149-157. (https://doi. org/10.1016/j.pan.2018.12.005)

Rifkin IR, Leadbetter EA, Busconi L, Viglianti G \& Marshak-Rothstein A 2005 Toll-like receptors, endogenous ligands, and systemic autoimmune disease. Immunological Reviews 204 27-42. (https://doi. org/10.1111/j.0105-2896.2005.00239.x)

Segerstolpe Å, Palasantza A, Eliasson P, Andersson EM, Andreasson AC, Sun X, Picelli S, Sabirsh A, Clausen M, Bjursell MK, et al. 2016 Single-cell transcriptome profiling of human pancreatic islets in 
health and type 2 diabetes. Cell Metabolism 24 593-607. (https://doi. org/10.1016/j.cmet.2016.08.020)

Shi H, Kokoeva MV, Inouye K, Tzameli I, Yin H \& Flier JS 2006 TLR4 links innate immunity and fatty acid-induced insulin resistance. Journal of Clinical Investigation 116 3015-3025. (https://doi.org/10.1172/ JCI28898)

Stridh L, Smith PL, Naylor AS, Wang X \& Mallard C 2011 Regulation of toll-like receptor 1 and -2 in neonatal mice brains after hypoxia-ischemia. Journal of Neuroinflammation 8 45. (https://doi. org/10.1186/1742-2094-8-45)

Strodthoff D, Ma Z, Wirström T, Strawbridge RJ, Ketelhuth DF, Engel D, Clarke R, Falkmer S, Hamsten A, Hansson GK, et al. 2015 Toll-like receptor 3 influences glucose homeostasis and beta-cell insulin secretion. Diabetes 64 3425-3438. (https://doi.org/10.2337/db14-0838)

Stuart T, Butler A, Hoffman P, Hafemeister C, Papalexi E, Mauck 3rd WM, Hao Y, Stoeckius M, Smibert P \& Satija R 2019 Comprehensive integration of single-cell data. Cell 177 1888.e21-1902.e21. (https:// doi.org/10.1016/j.cell.2019.05.031)

Sun S, Ji Y, Kersten S \& Qi L 2012 Mechanisms of inflammatory responses in obese adipose tissue. Annual Review of Nutrition 32 261-286. (https://doi.org/10.1146/annurev-nutr-071811-150623)

Uchida M, Oyanagi E, Kawanishi N, Iemitsu M, Miyachi M, Kremenik MJ, Onodera S \& Yano H 2014 Exhaustive exercise increases the TNFalpha production in response to flagellin via the upregulation of tolllike receptor 5 in the large intestine in mice. Immunology Letters 158 151-158. (https://doi.org/10.1016/j.imlet.2013.12.021)

Uthaya Kumar DB, Chen CL, Liu JC, Feldman DE, Sher LS, French S, DiNorcia J, French SW, Naini BV, Junrungsee S, et al. 2016 TLR4 signaling via NANOG cooperates with STAT3 to activate Twist1 and promote formation of tumor-initiating stem-like cells in livers of mice. Gastroenterology 150 707-719. (https://doi.org/10.1053/j. gastro.2015.11.002)

Vila IK, Badin PM, Marques MA, Monbrun L, Lefort C, Mir L, Louche K, Bourlier V, Roussel B, Gui P, et al. 2014 Immune cell toll-like receptor
4 mediates the development of obesity- and endotoxemia-associated adipose tissue fibrosis. Cell Reports 7 1116-1129. (https://doi. org/10.1016/j.celrep.2014.03.062)

Vives-Pi M, Somoza N, Fernandez-Alvarez J, Vargas F, Caro P, Alba A, Gomis R, Labeta MO \& Pujol-Borrell R 2003 Evidence of expression of endotoxin receptors CD14, toll-like receptors TLR4 and TLR2 and associated molecule MD-2 and of sensitivity to endotoxin (LPS) in islet beta cells. Clinical and Experimental Immunology 133 208-218. (https://doi.org/10.1046/j.1365-2249.2003.02211.x)

Wali JA, Gurzov EN, Fynch S, Elkerbout L, Kay TW, Masters SL \& Thomas HE 2014 Activation of the NLRP3 inflammasome complex is not required for stress-induced death of pancreatic islets. PLOS ONE 9 e113128. (https://doi.org/10.1371/journal.pone.0113128)

Wen L, Ley RE, Volchkov PY, Stranges PB, Avanesyan L, Stonebraker AC, Hu C, Wong FS, Szot GL, Bluestone JA, et al. 2008 Innate immunity and intestinal microbiota in the development of type 1 diabetes. Nature 455 1109-1113. (https://doi.org/10.1038/nature07336)

Wen H, Gris D, Lei Y, Jha S, Zhang L, Huang MT, Brickey WJ \& Ting JP 2011 Fatty acid-induced NLRP3-ASC inflammasome activation interferes with insulin signaling. Nature Immunology 12 408-415. (https://doi.org/10.1038/ni.2022)

Wen L, Peng J, Li Z \& Wong FS 2004 The effect of innate immunity on autoimmune diabetes and the expression of toll-like receptors on pancreatic islets. Journal of Immunology 172 3173-3180. (https://doi. org/10.4049/jimmunol.172.5.3173)

Westwell-Roper C, Nackiewicz D, Dan M \& Ehses JA 2014 Toll-like receptors and NLRP3 as central regulators of pancreatic islet inflammation in type 2 diabetes. Immunology and Cell Biology 92 314-323. (https://doi.org/10.1038/icb.2014.4)

Ying W, Lee YS, Dong Y, Seidman JS, Yang M, Isaac R, Seo JB, Yang BH, Wollam J, Riopel M, et al. 2019 Expansion of islet-resident macrophages leads to inflammation affecting beta cell proliferation and function in obesity. Cell Metabolism 29 457.e5-474.e5. (https:// doi.org/10.1016/J.cmet.2018.12.003)

Received in final form 19 July 2020

Accepted 4 August 2020

Accepted Manuscript published online 4 August 2020 (c) 2020 Society for Endocrinology Published by Bioscientifica Ltd. Printed in Great Britain 